\title{
Production of Microbial Industrial Enzymes
}

\section{Francois Niyongabo Niyonzima*}

Department of Biotechnologies, Faculty of Applied Fundamental Sciences, INES-Ruhengeri, Musanze, Rwanda

*Corresponding Author: Francois Niyongabo Niyonzima, Department of Biotechnologies, Faculty of Applied Fundamental Sciences, INES-Ruhengeri, Musanze, Rwanda.

Received: October 17, 2019; Published: November 11, 2019

DOI: $10.31080 /$ ASMI.2019.02.0434

\begin{abstract}
Microbial enzymes are biological catalysts due to their ability to favor reactions more quickly and more efficiently. Various enzymes are produced by microorganisms for industry uses. They must possess the desired properties like diversified functionality, and stability over a pH and temperature ranges. The microorganisms have to produce extracellular enzymes in higher amounts and the produced enzymes have to be safe, stable, and more active. The microbial enzymes with the desired properties can be produced by optimizing fermentation conditions. To make the fermentation cost-effective, the utilization of low cost substrates such as agricultural and spent residues for microbial enzymes production is necessary. Some industrial enzymes used together for the same purpose (like amylase, lipase and protease used in detergent formulation) are co-produced together in a single fermentation to reduce the cost and to maintain the enzyme stability. In addition, for some microorganisms, recombinant DNA technology is used as an alternative strategy for overproducing huge amounts of microbial enzymes with improved substrate specificity and stability. Furthermore, novel techniques like genetic fusion of coding open reading frames or connection of proteins in a post translational process are used to manufacture the fused industrial enzymes having combined properties of their parental molecules. The public and private companies have thus to work together with academicians in order to overproduce microbial enzymes needed by the industries. The present article reviews the production of industrial enzymes and optimization of culture and fermentation conditions in order to produce microbial enzymes in huge amounts.
\end{abstract}

Keywords: Industrial Enzyme; Fermentation; Optimization; Production; Microbial Enzyme

\section{Introduction}

Enzymes are considered as wonderfully specific and efficient biocatalysts for a large number of biochemical reactions. They are not toxic and generate few byproducts, compared to chemical catalysts. Industrial enzymes with specific characteristics can be obtained from microorganisms by optimizing process parameters and by enzyme engineering. Various enzymes such as proteases, amylases, cellulases, and lipases were engineered in order to work under industrial conditions. This is necessary as wild microbial strains produce a lesser amount of enzyme, compared to engineered microorganisms. This can be achieved using special methods like use of mutagens [1,2].

The industrial enzymes are drived from plants, animals, and microorganisms. However, the microorganisms are in use to produce these enzymes owing to an important yield obtained from them, and reduction of cost and labor. Most of the industrial enzymes are secreted by Bacillus [3-16] and Aspergillus species [17-27]. Some industrial enzymes having same application can be co-produced in a single fermentation medium. In this case, the production process becomes cost effective and the enzyme stability is assured. The role of medium composition optimization is to maintain the balance between the different medium ingredients thereby preventing the amount of unused components at the end of fermentation process [28]. Kumar and Takagi [29] reported that there is no specific growth medium for the optimum industrial enzyme production by bacteria or fungi. Each bacterial or fungal species has its own growth conditions to produce industrial enzymes in a significant amount. According to Hajji., et al. [30], the growth medium for industrial enzymes production by bacteria and fungi is mainly optimized with the one parameter at a time method. Statistical methods are also employed to produce the industrial enzymes in adequate amounts.

Industries are still searching for new microbial strains with desired aspects in order to produce various industrial enzymes to 
fulfil the current enzymes demand. The proper selection of different industrial microorganisms and the optimization of fermentation conditions is thus necessary to produce inexpensive industrial enzymes. The production of microbial industrial enzymes under optimized conditions to get enzymes with desirable properties is a continuous exercise. The concomitant production of industrial enzymes in a single-economic production medium from microorganisms is also a new challenge. Although some important works has been reported for the production and optimization of industrial enzymes from microorganisms, there is no specific report for the industrial production and optimization of culture conditions for maximum industrial enzyme production. The present review therefore reports the production and optimization of culture and fermentation conditions to produce industrial enzymes from microorganisms in important amounts. The isolation and identification of industrial enzyme-producing microorganisms were first described.
Isolation and screening of industrial enzyme-producing microorganisms

The industrial enzyme-producing microorganisms are generally isolated from soil samples collected from various places [49,11-13,15-17,18,20-22,24,26,27,31-35]. They are also obtained from plant bark [25]), watery environment [36,37], skim milk [3]), marine sediment [38-41], municipal solid wastes [14] and from grapes [42] (Table 1). The microorganisms producing industrial enzymes are usually screened from samples by serial dilution followed by spread plating on specific agar medium depending on the enzyme of interest to be produced by microorganisms (Table 1). Therefore, the selected isolation and screening medium contains an industrial enzyme inducer. For instance, the laccase production by Scytalidium lignicola was stimulated by $\mathrm{CuSO}_{4}$ and $\mathrm{MgSO}_{4}$ [43]. Some proteases may require casein, skim milk or gelatin as inducer $[3,8,21,33,36,37,39]$. The amylases, cellulases, and lipases may require starches $[4,14,15,31,34,44,45]$, carboxymethylcellulose $[13,32,35,46,47]$, and oil substances as inducers $[32,41]$, respectively (Table 1).

\begin{tabular}{|c|c|c|c|c|c|}
\hline $\begin{array}{l}\text { Enzyme } \\
\text { produced }\end{array}$ & Microorganism & Source of isolation & Screening medium & Identification & Reference \\
\hline Lipase & $\begin{array}{c}\text { Acinetobacter } \\
\text { calcoaceticus 1-7 }\end{array}$ & soil & olive oil agar & 16S rDNA analysis & [32] \\
\hline Protease & Aspergillus niger & soil & casein agar & $\begin{array}{l}\text { cultural and microscopic } \\
\text { characteristics }\end{array}$ & [19] \\
\hline Pectinase & Aspergillus niger & soil & pectin agar & $\begin{array}{l}\text { cultural and } \\
\text { morphological character- } \\
\text { istics }\end{array}$ & {$[20]$} \\
\hline Phytase & Aspergillus niger & rhizosphere soil & phytate agar & 18S rRNA sequence & {$[22]$} \\
\hline Tannase & Aspergillus niger & plant barks & tannate agar & $\begin{array}{l}\text { morphological and micro- } \\
\text { scopic features }\end{array}$ & {$[25]$} \\
\hline Cellulase & Aspergillus awamori & wood chips soil & $\begin{array}{l}\text { carboxy methyl cel- } \\
\text { lulose (CMC) agar }\end{array}$ & 18s rRNA sequencing & {$[27]$} \\
\hline Keratinase & Aspergillus niger / flavus & poultry farm soil & feather keratin agar & $\begin{array}{l}\text { morphological and micro- } \\
\text { scopic features }\end{array}$ & {$[18]$} \\
\hline Invertase & Aspergillus sojae JU12 & sugarcane soil & PDA & $\begin{array}{l}\text { 18S rRNA molecular } \\
\text { sequencing }\end{array}$ & [26] \\
\hline Tannase & Aspergillus sp. GM4 & laboratory & tannate agar & $\begin{array}{l}\text { morphological and micro- } \\
\text { scopic features }\end{array}$ & {$[23]$} \\
\hline Protease & Aspergillus terreus gr. & $\begin{array}{l}\text { potato grown soil } \\
\text { fields }\end{array}$ & casein agar & $\begin{array}{l}\text { morphological and micro- } \\
\text { scopic features }\end{array}$ & {$[21]$} \\
\hline Tannase & $\begin{array}{l}\text { Aspergillus tubingensis } \\
\text { CICC } 2651\end{array}$ & soil & tannate agar & $\begin{array}{l}\text { morphological and micro- } \\
\text { scopic features }\end{array}$ & {$[24]$} \\
\hline Protease & $\begin{array}{c}\text { Aspergillus versicolor } \\
\text { PF/F/107 }\end{array}$ & poultry farm soil & Reese media & $\begin{array}{l}\text { morphological and micro- } \\
\text { scopic features }\end{array}$ & [17] \\
\hline Protease & Bacillus cereus & skim milk & $\begin{array}{l}\text { nutrient agar and skim } \\
\text { milk }\end{array}$ & 16S rRNA analysis & [3] \\
\hline
\end{tabular}




\begin{tabular}{|c|c|c|c|c|c|}
\hline Pullulanase & Bacillus cereus & $\begin{array}{l}\text { baking wastes, soil, } \\
\text { and } \\
\text { food wastes }\end{array}$ & soluble pullulan agar & $\begin{array}{l}\text { morphological and bio- } \\
\text { chemical } \\
\text { experiments }\end{array}$ & [11] \\
\hline Amylase & Bacillus cereus GA6 & soil & starch agar & 16S rRNA analysis & {$[7]$} \\
\hline L-glutaminase & Bacillus cereus FT9 & soil & L-glutamine agar & 16S rRNA analysis & [12] \\
\hline L-glutaminase & Bacillus cereus LC13 & marine soil & $\begin{array}{l}\text { minimal glutamine } \\
\text { agar }\end{array}$ & 16s rRNA analysis & [16] \\
\hline CGTase & Bacillus flexus MSBC 2 & corn field soil & soluble starch agar & 16s rRNA analysis & [15] \\
\hline Lipase & Bacillus flexus XJU-1 & potato field soil & tween 80 agar & 16S rDNA analysis & [6] \\
\hline CGTase & Bacillus halodurans & sugarcane soil & soluble starch agar & $\begin{array}{l}\text { microscopic examination } \\
\text { and biochemical tests }\end{array}$ & [31] \\
\hline Pullulanase & Bacillus halodurans & soil & pullulan agar & $\begin{array}{l}\text { microscopic examination } \\
\text { and biochemical tests }\end{array}$ & {$[5]$} \\
\hline Phytase & Bacillus lehensis MLB2 & bean-grown soil & phytate agar & $\begin{array}{c}\text { morphological and physi- } \\
\text { ological } \\
\text { aspects }\end{array}$ & [10] \\
\hline Amylase & $\begin{array}{c}\text { Bacillus licheniformis } \\
\text { AS08E }\end{array}$ & soil & starch agar & 16S rDNA analysis & [34] \\
\hline Protease & $\begin{array}{l}\text { Bacillus licheniformis } \\
\text { KBDL4 }\end{array}$ & soda lake water & casein agar & 16S rDNA analysis & [36] \\
\hline Keratinase & Bacillus megaterium & $\begin{array}{l}\text { poultry dump yards } \\
\text { soil }\end{array}$ & feather meal agar & $\begin{array}{l}\text { microscopic examination } \\
\text { and biochemical tests }\end{array}$ & [59] \\
\hline Cellulase & $\begin{array}{l}\text { Bacillus megaterium } \\
\text { BMS4 }\end{array}$ & soil & $\begin{array}{l}\text { carboxymethylcellu- } \\
\text { lose agar }\end{array}$ & 16S rDNA analysis & [35] \\
\hline Lipase & Bacillus smithii BTMS 11 & marine sediment & ZoBell's marine agar & sequence analysis & [40] \\
\hline Lipase & Bacillus sonorensis & marine clams & olive oil agar & sequence analysis & [41] \\
\hline Amylase & Bacillus sp. & $\begin{array}{c}\text { municipal } \\
\text { solid wastes }\end{array}$ & starch agar & 16S rDNA analysis & [14] \\
\hline Protease & Bacillus sp. PX6 & soil & skim milk agar & $\begin{array}{l}\text { VITEK } 2 \text { bacteria identifi- } \\
\text { cation system }\end{array}$ & [8] \\
\hline Cellulase & Bacillus sp., MSL2 & rice paddy field soil & $\begin{array}{l}\text { carboxymethyl cel- } \\
\text { lulose agar }\end{array}$ & 16S rDNA gene & [13] \\
\hline Pectinase & Bacillus subtilis & soil & pectin agar & $\begin{array}{l}\text { culture and biochemical } \\
\text { aspects }\end{array}$ & [9] \\
\hline Amylase & Bacillus subtilis AS-S01a & soil & starch agar & 16S rRNA analysis & [4] \\
\hline Amylase & Chryseobacterium sp. & $\begin{array}{c}\text { municipal } \\
\text { solid wastes }\end{array}$ & starch agar & 16S rDNA analysis & [14] \\
\hline Xylanase & Fusarium sp. XPF-5 & $\begin{array}{l}\text { soil rich in plant } \\
\text { dead material }\end{array}$ & xylan & $\begin{array}{l}\text { morphological and micro- } \\
\text { scopic features }\end{array}$ & [64] \\
\hline Tannase & $\begin{array}{l}\text { Mucor circinelloides } \\
\text { F6-3-12 }\end{array}$ & soil & tannic acid agar & $\begin{array}{c}18 \mathrm{~S} \text { rRNA } \\
\text { gene sequencing } \\
\end{array}$ & [63] \\
\hline L-asparaginase & Mucor hiemalis & soil & L-asparagine agar & $\begin{array}{l}\text { morphological and micro- } \\
\text { scopic features }\end{array}$ & [56] \\
\hline$\beta$-amylase & Penicillium nigricans & forest soil & starch agar & $\begin{array}{l}\text { morphological and micro- } \\
\text { scopic features }\end{array}$ & [45] \\
\hline
\end{tabular}




\begin{tabular}{|c|c|c|c|c|c|}
\hline Cellulase & Penicillium sp. & $\begin{array}{l}\text { soil polluted with } \\
\text { effluents }\end{array}$ & cellulose lactose agar & $\begin{array}{l}\text { morphological and micro- } \\
\text { scopic features }\end{array}$ & [47] \\
\hline Cellulase & Pseudomonas fluorescens & soil & CMC agar & $\begin{array}{l}\text { morphological examina- } \\
\text { tion } \\
\text { and biochemical charac- } \\
\text { terizations }\end{array}$ & [46] \\
\hline Amylase & $\begin{array}{c}\text { Pseudomonas stutzeri } \\
\text { AS22 }\end{array}$ & soil & starch agar & 16S rDNA analysis & [44] \\
\hline Invertase & Saccharomyces cerevisiae & grapes & sucrose agar & $\begin{array}{l}\text { biochemical tests and } \\
\text { microscopic studies }\end{array}$ & [42] \\
\hline Protease & Scopulariopsis sp. & poultry yards soil & skim milk agar & $\begin{array}{l}\text { morphological and micro- } \\
\text { scopic features }\end{array}$ & [33] \\
\hline Laccase & Scytalidium lignicola & soil & $\begin{array}{c}\text { guaiacol and } \\
\text { 2,2'-azinobis-(3- ethyl- } \\
\text { benzthiazoline-6-sul- } \\
\text { fonate) (ABTS) agar }\end{array}$ & $\begin{array}{l}\text { morphological and micro- } \\
\text { scopic features }\end{array}$ & [43] \\
\hline Xylanase & $\begin{array}{l}\text { Sphingobacterium sp. } \\
\text { SaH-05 }\end{array}$ & $\begin{array}{l}\text { farmland environ- } \\
\text { ment }\end{array}$ & xylan agar & 16s rRNA analysis & [61] \\
\hline Laccase & Stereum ostrea & wood logs & peptone glucose agar & $\begin{array}{l}\text { morphological and micro- } \\
\text { scopic features }\end{array}$ & [65] \\
\hline Amylase & Streptomyces sp. A3 & marine sediment & starch agar & 16S rDNA analysis & [38] \\
\hline Protease & Trichoderma estonicum & mangrove sediment & $\begin{array}{l}\text { glucose yeast peptone } \\
\text { amended with } 0.4 \% \\
\text { gelatin }\end{array}$ & $\begin{array}{l}\text { morphological and micro- } \\
\text { scopic characteristics }\end{array}$ & [39] \\
\hline L-asparaginase & $\begin{array}{l}\text { Trichoderma viride Pers: } \\
\text { SF Grey }\end{array}$ & marine soil & L-asparagine agar & $\begin{array}{l}\text { morphological and micro- } \\
\text { scopic features }\end{array}$ & [57] \\
\hline Protease & Virgibacillus sp. EMB13 & sea water & gelatin agar & 16S rDNA analysis & [37] \\
\hline
\end{tabular}

Table 1: Isolation, screening and identification of industrial enzyme-producing microorganisms.

The formation of clear zone of specific substrate hydrolysis on agar medium plates around the microorganism is an indication of an industrial enzyme secretion by the microorganism. For example, the industrial microbial amylases produce clear zones after starch hydrolysis $[14,45]$. Similarly, a clear zone of casein/gelatin hydrolysis on agar plates around the organism is observed in the case of protease $[3,8,21,33,36,37,39]$. Furthermore, the tributyrin / Tween 80 hydrolysis or color change from red to yellow for oilphenol red agar plate or appearance of orange fluorescent halos around industrial microorganism under UV light at $350 \mathrm{~nm}$, is seen for industrial lipase secreted by microorganisms $[6,32,40,41,48]$. The color change is due to the release of fatty acids from oil hydrolysis that lowers the medium to the acidic pH (yellow color) [49]. The appearance of orange fluorescent halos occurred as a result of the complexation between the Rhodamine B and the oil hydrolysis products (fatty acids, mono- and diglycerides) [50].

To visualize clearly the hydrolysis zones, the culture Petri plates may be flooded with $0.1 \%$ Congo red solution followed by $1 \mathrm{M}$ sodium chloride solution in the case of cellulase $[13,46]$, saturated aqueous ammonium sulfate [39] or $10 \%$ trichloroacetic acid (TCA) or $15 \%$ of $\mathrm{HgCl} 2$ [21,51-53] in the case of protease, the Gram's iodine solution in the case of amylases [54,55], and phenol red that gets converted into pink color in the case of L-asparaginase [56,57]. When isolating and screening industrial enzymes, nystatin is added to the culture medium before being poured in to Petri plates to prevent fungal growth, whereas tetracycline is added to the plates for bacterial growth prevention. To isolate alkalophilic industrial enzymes-producing microorganisms, sodium carbonate is generally added to the growth medium $[6,21,33]$. Indeed, sodium carbonate serves as a major source of alkalinity in natural environments and when supplemented to the culture medium, the alkalophilic microorganisms used in industries under basic conditions are produced [58].

Identification of industrial enzyme-producing microorganisms

The identification of industrial enzyme-producing microorganisms, especially those which are non-toxic to human beings, are of high strategic interest. The industrial enzymes-producing bac- 
teria are identified by morphological, cultural, microscopic, and biochemical characteristics [5,8-11,31,40,41,59] as cleared in the Bergey's manual of determinative bacteriology [60]. The identity is further verified and confirmed by molecular techniques such as $16 \mathrm{~S}$ rRNA $[3,4,7,12,15,16,61]$ or $16 \mathrm{~S}$ rDNA sequence analysis $[13,14,33-38,44]$ (Table 1). The industrial enzymes-producing fungi are traditionally identified on the basis of cultural, morphological and microscopic features [17-21,23-25,33,42,43,45,47,56,57,62]. The identity is further confirmed by $18 \mathrm{~S}$ rRNA [22,26,63] sequence analysis in some cases (Table 1). Unlike for bacteria where the genomes of several bacteria have been sequenced, the fungal sequence analysis is at initial stages for fungi producing industrial enzymes. After rRNA / rDNA bacterial gene sequencing or $18 \mathrm{~S}$ rRNA fungal molecular sequencing, the genomes have showed several new genes, and most of them were coding for industrial enzymes.

Production of microbial industrial enzymes by microorganisms

Industrial enzymes are enzymes used by various industries for commercial purpose. Production of industrial enzymes by microorganisms is a necessary step in industrial sectors. The production of industrial enzymes from microorganisms involves various steps. These are isolation, screening and identification of enzymesproducing microorganisms, optimization of process parameters and fermentation for industrial enzyme production, purification and characterization of purified enzymes, industrial enzymes formulation for sale, customer liaison, and working with the regulatory authority bodies (Figure 1). Most of the bacteria and fungi used to produce industrial enzymes are genetically modified to overproduce them in significant amount $[22,66]$. Solid state and submerged fermentation are often used to produce industrial enzymes. However, the submerged fermentation was repeatedly reported to be the method of choice for industrial enzymes secretion from microorganisms owing to the extracellular nature of the industrial enzyme that gets liberated in to the production medium. Sarrouh., et al. [66] reported that $\mathrm{pH}$ and temperature stability, specificity, influence of activators and inhibitors, and reaction velocity are some of the criteria used in the selection of the industrial enzymes to be produced by microorganisms.

Industrial enzymes are generally produced under carefully controlled conditions by fermentation using microorganisms, especially bacteria or fungi. Bacillus and Aspergillus species were reported to be the main producers of industrial enzymes (Table 2 and 3). Indeed, most of the species of these genera are safe and not producing any toxin, grow on inexpensive substrates and secrete extracellularly adequate amounts of enzymes in a reason- able time period. They can also be genetically manipulated easily to give novel industrial enzymes with desirable characteristics [67]. The microorganisms belonging to the Acinetobacter, Pseudomonas, Staphylococcus, Streptomyces, Fusarium, Mucor, Penicillium, and Trichoderma species are also used for industrial enzymes production (Table 2 and 3).

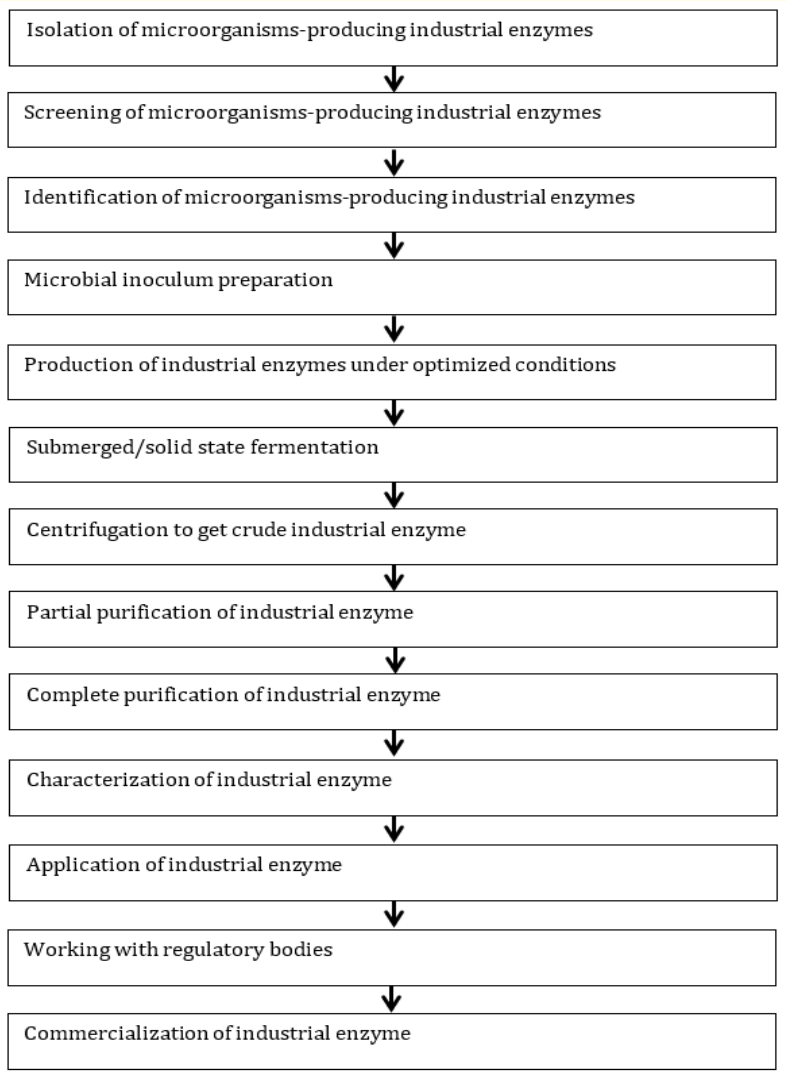

Figure 1: Production of industrial enzymes by microorganisms.

For the industrial production of microbial enzymes, submerged fermentation (SMF) and/or solid state fermentation (SSF) are employed. Each fermentation has its advantges and disadvantages. Indeed, ssubmerged fermentation is often utilized to produce industrial microbial enzymes [3,9-16,21-25,27,33,36,37,68]. It allows extracellular industrial enzyme secretion in important amounts in the production medium and thus industrial enzyme recovery is high. In addition, the culture parameters are easily controlled. However, one of the disadvantages of $\mathrm{SmF}$ is that it uses expensive synthetic media $[6,40]$.

Solid-state fermentation is also used for some industrial enzymes production [26]. It uses inexpensive substances like agroindustrial by-products and downstream process is not expensive. 


\begin{tabular}{|l|c|c|c|}
\hline \multicolumn{1}{|c|}{ Substrate used } & Enzymes produced & Microorganism & Reference \\
\hline Chicken feathers & Keratinase & Bacillus megaterium & {$[59]$} \\
\hline Jamun leaves & Tannase & Aspergillus sp. GM4 & {$[23]$} \\
\hline Molasses & Neutral invertase & Aspergillus sp & {$[71]$} \\
\hline Orange peel moistened with molasses & Invertase & Aspergillus sojae JU12 & {$[26]$} \\
\hline Organic kitchen wastes & Amylase & Chryseobacterium sp. \\
& & Bacillus sp. & {$[14]$} \\
\hline Rice bran & Phytase & Bacillus lehensis MLB2 & [10] \\
\hline Rice bran and wheat bran & Laccase & Stereum ostrea & [65] \\
\hline Saw-dust & Cellulase & Penicillium sp. & {$[47]$} \\
\hline Sugarcane bagasse & Cellulase & Aspergillus awamori & {$[27]$} \\
\hline Sugarcane bagasse or straw, wheat bran, dry corn, sawdust & Cellulase & Pseudomonas fluorescens & {$[46]$} \\
\hline Tea stalks & Tannase & Aspergillus tubingensis CICC 2651 & {$[24]$} \\
\hline Wheat bran & Keratinase & Aspergillus niger/flavus & {$[18]$} \\
\hline Wheat bran & Phytase & Aspergillus niger & {$[22]$} \\
\hline Wheat bran & Xylanase & Sphingobacterium sp. SaH-05 & {$[61]$} \\
\hline
\end{tabular}

Table 2: Low cost substrates used during industrial enzymes production by microorganisms.

\begin{tabular}{|c|c|c|c|c|c|c|c|c|c|}
\hline Microorganism & $\begin{array}{l}\text { Enzyme } \\
\text { produced }\end{array}$ & pH & $\mathbf{T}\left({ }^{\circ} \mathrm{C}\right)$ & $\begin{array}{l}\text { Agitation } \\
\text { (rpm) }\end{array}$ & $\begin{array}{l}\text { Inoculum } \\
\text { size (\%) }\end{array}$ & $\begin{array}{c}\text { Incubation } \\
\text { period }\end{array}$ & Good C source & $\begin{array}{c}\text { Preferred N } \\
\text { source }\end{array}$ & Reference \\
\hline \multicolumn{10}{|l|}{ Bacterial species } \\
\hline $\begin{array}{l}\text { Acinetobacter } \\
\text { calcoaceticus 1-7 }\end{array}$ & Lipase & 9 & 37 & 180 & 0.6 & $48 \mathrm{~h}$ & starch, olive oil, & $\begin{array}{l}\text { corn flour } \\
\text { bean flour }\end{array}$ & [32] \\
\hline Bacillus cereus & Protease & 10 & 37 & $\mathrm{~ns}$ & 2 & $48 \mathrm{~h}$ & $\begin{array}{l}\text { glucose and } \\
\text { skim milk }\end{array}$ & $\begin{array}{l}\text { peptone and } \\
\text { yeast extract }\end{array}$ & [3] \\
\hline Bacillus cereus & Pullulanase & 6 & 50 & 200 & ns & $48 \mathrm{~h}$ & $\begin{array}{c}\text { soluble } \\
\text { pullulan }\end{array}$ & tryptone & [11] \\
\hline Bacillus cereus GA6 & Amylase & 10 & 20 & 120 & 1 & $96 \mathrm{~h}$ & glycerol & $\begin{array}{l}\text { ammonium } \\
\text { acetate }\end{array}$ & [7] \\
\hline Bacillus cereus FT9 & L-glutaminase & 7 & 37 & 150 & ns & $24 \mathrm{~h}$ & malt extract & peptone & [12] \\
\hline Bacillus cereus LC13 & L-Glutaminas & 7 & 37 & 100 & ns & $24 \mathrm{~h}$ & maltose & L-glutamine & [16] \\
\hline $\begin{array}{l}\text { Bacillus flexus MSBC } \\
2\end{array}$ & CGTase & 10 & 37 & ns & ns & $120 \mathrm{~h}$ & corn starch & $\begin{array}{l}\text { peptone with } \\
\text { yeast extract }\end{array}$ & [15] \\
\hline Bacillus flexus XJU-1 & Lipase & 11 & 37 & 100 & 2 & $36 \mathrm{~h}$ & cotton seed oil & yeast extract & [6] \\
\hline Bacillus halodurans & CGTase & 10.5 & 37 & ns & ns & $48 \mathrm{~h}$ & Soluble starch & $\begin{array}{l}\text { yeast extract } \\
\text { and peptone }\end{array}$ & [31] \\
\hline Bacillus halodurans & Pullulanase & 10 & 37 & ns & ns & $72 \mathrm{~h}$ & pullulan & peptone & {$[5]$} \\
\hline $\begin{array}{l}\text { Bacillus lehensis } \\
\text { MLB2 }\end{array}$ & Phytase & 5.5 & 30 & 100 & 2 & $24 \mathrm{~h}$ & rice bran & $\begin{array}{l}\text { potassium } \\
\text { nitrate }\end{array}$ & [10] \\
\hline $\begin{array}{l}\text { Bacillus } \\
\text { licheniformis AS08E }\end{array}$ & Amylase & ns & 45 & 200 & ns & $60 \mathrm{~h}$ & ns & ns & {$[34]$} \\
\hline $\begin{array}{l}\text { Bacillus } \\
\text { licheniformis KBDL4 }\end{array}$ & Protease & 10 & 37 & 200 & 3 & $48 \mathrm{~h}$ & casein & yeast extract & [36] \\
\hline $\begin{array}{l}\text { Bacillus } \\
\text { megaterium }\end{array}$ & Keratinase & 10 & 37 & ns & ns & $72 \mathrm{~h}$ & feather meal & $\begin{array}{l}\text { feather meal } \\
\text { supplemented } \\
\text { with yeast } \\
\text { extract }\end{array}$ & [59] \\
\hline
\end{tabular}




\begin{tabular}{|c|c|c|c|c|c|c|c|c|c|}
\hline $\begin{array}{l}\text { Bacillus } \\
\text { megaterium BMS4 }\end{array}$ & Cellulase & 7 & 37 & 120 & ns & $24 \mathrm{~h}$ & sucrose & $\begin{array}{l}\text { LB medium } \\
\text { BHM medium }\end{array}$ & [35] \\
\hline $\begin{array}{l}\text { Bacillus smithii } \\
\text { BTMS } 11\end{array}$ & Lipase & 8 & 28 & 170 & 3 & $24 \mathrm{~h}$ & $\begin{array}{l}\text { glucose, sesame } \\
\text { oil }\end{array}$ & soybean meal & [40] \\
\hline Bacillus sonorensis & Lipase & ns & 40 & 150 & 1 & $48 \mathrm{~h}$ & olive oil & $\begin{array}{l}\text { peptone and } \\
\text { yeast extract }\end{array}$ & [41] \\
\hline Bacillus sp. & Amylase & 7 & 50 & 120 & 2 & $48 \mathrm{~h}$ & soluble starch & peptone & [14] \\
\hline Bacillus sp. SMIA-2 & Protease & 8.5 & 50 & 150 & $\mathrm{~ns}$ & $36 \mathrm{~h}$ & starch & $\begin{array}{l}\text { whey protein } \\
\text { and corn steep } \\
\text { liquor }\end{array}$ & [68] \\
\hline Bacillus sp., MSL2 & Cellulase & 6 & 50 & 200 & & $48 \mathrm{~h}$ & $\begin{array}{l}\text { carboxymethyl- } \\
\text { cellulose }\end{array}$ & yeast extract & [13] \\
\hline Bacillus subtilis & Pectinase & 8.5 & 37 & ns & ns & $24 \mathrm{~h}$ & glucose & yeast extract & [9] \\
\hline $\begin{array}{l}\text { Bacillus subtilis AS- } \\
\text { S01a }\end{array}$ & Amylase & 6 & 35 & 150 & ns & $60 \mathrm{~h}$ & starch & beef extract & [4] \\
\hline Chryseobacterium sp. & Amylase & 5 & 50 & 120 & 2 & $60 \mathrm{~h}$ & glucose & peptone & [14] \\
\hline $\begin{array}{l}\text { Pseudomonas } \\
\text { fluorescens }\end{array}$ & Cellulase & 10 & 40 & ns & ns & $24 \mathrm{~h}$ & glucose & $\begin{array}{l}\text { ammonium } \\
\text { sulphate }\end{array}$ & [46] \\
\hline $\begin{array}{l}\text { Pseudomonas } \\
\text { stutzeri AS22 }\end{array}$ & Amylase & 8 & 30 & 200 & ns & $24 \mathrm{~h}$ & potato starch & yeast extract & {$[44]$} \\
\hline $\begin{array}{l}\text { Sphingobacterium } \\
\text { sp. SaH-05 }\end{array}$ & Xylanase & 8 & 37 & 150 & ns & $24 \mathrm{~h}$ & wheat bran & $\begin{array}{l}\text { ammonium } \\
\text { sulfate }\end{array}$ & {$[61]$} \\
\hline $\begin{array}{l}\text { Staphylococcus arlet- } \\
\text { tae JPBW-1 }\end{array}$ & Lipase & 8 & 35 & 100 & 10 & $48 \mathrm{~h}$ & soybean oil & ns & [76] \\
\hline Streptomyces sp. A3 & Amylase & 9 & 45 & 200 & 2 & $168 \mathrm{~h}$ & maltose & peptone & [38] \\
\hline $\begin{array}{l}\text { Virgibacillus sp. } \\
\text { EMB13 }\end{array}$ & Protease & 8 & 30 & 150 & 4 & $24 \mathrm{~h}$ & mannitol & $\begin{array}{l}\text { peptone and } \\
\text { yeast extract }\end{array}$ & [37] \\
\hline \multicolumn{10}{|l|}{ Fungal species } \\
\hline Aspergillus niger & Pectinase & 4.5 & 30 & 150 & ns & 7 days & pectin & peptone & [20] \\
\hline Aspergillus niger & Phytase & 5 & 30 & 200 & ns & 4 days & glucose & $\begin{array}{l}\text { ammonium } \\
\text { nitrate }\end{array}$ & [22] \\
\hline Aspergillus niger & Tannase & 4 & 37 & 120 & ns & 4 days & tannate & yeast extract & [25] \\
\hline Aspergillus awamori & Cellulase & 6 & 25 & ns & ns & 7 days & $\begin{array}{l}\text { carboxy methyl } \\
\text { cellulose (CMC) }\end{array}$ & peptone & [27] \\
\hline $\begin{array}{l}\text { Aspergillus niger / } \\
\text { flavus }\end{array}$ & Keratinase & 8.5 & 37 & 120 & ns & 4 days & keratin & peptone & [18] \\
\hline $\begin{array}{l}\text { Aspergillus sojae } \\
\text { JU12 }\end{array}$ & Invertase & 8 & 37 & ns & 9 & 5 days & $\begin{array}{c}\text { orange peel } \\
\text { moistened } \\
\text { with molasses }\end{array}$ & beef extract & [26] \\
\hline Aspergillus sp. GM4 & Tannase & 4 & 30 & ns & ns & 4 days & $\begin{array}{c}\text { jamun leaves / } \\
\text { tannate }\end{array}$ & $\begin{array}{c}\text { potassium } \\
\text { nitrate }\end{array}$ & [23] \\
\hline $\begin{array}{l}\text { Aspergillus terreus } \\
\text { gr. }\end{array}$ & Protease & 10 & 37 & $\mathrm{~ns}$ & 2 & 5 days & casein & soybean meal & [21] \\
\hline $\begin{array}{l}\text { Aspergillus versi- } \\
\text { color } \mathrm{PF} / \mathrm{F} / 107\end{array}$ & Protease & 9 & 35 & 150 & $\mathrm{~ns}$ & 4 days & wheat bran & sodium nitrate & [17] \\
\hline Fusarium sp. XPF-5 & Xylanase & 8 & 47 & 160 & ns & 4 days & xylan & ns & [64] \\
\hline $\begin{array}{l}\text { Mucor circinelloides } \\
\text { F6-3-12 }\end{array}$ & Tannase & 5.5 & 30 & 200 & 2 & 7 days & $\begin{array}{l}\text { green tea } \\
\text { leaves powder }\end{array}$ & Sodium nitrate & [63] \\
\hline
\end{tabular}




\begin{tabular}{|l|c|c|c|c|c|c|c|c|c|}
\hline Mucor hiemalis & $\begin{array}{c}\text { L-asparagi- } \\
\text { nase }\end{array}$ & 7 & 30 & $\mathrm{~ns}$ & $\mathrm{~ns}$ & 4 days & glucose & L-asparagine & {$[56]$} \\
\hline $\begin{array}{l}\text { Penicillium nigri- } \\
\text { cans }\end{array}$ & $\boldsymbol{\beta}$-amaylase & 5 & 60 & $\mathrm{~ns}$ & $\mathrm{~ns}$ & $\mathrm{~ns}$ & starch & sodium nitrite & {$[45]$} \\
\hline Penicillium sp. & Cellulase & 5 & 30 & $\mathrm{~ns}$ & $\mathrm{~ns}$ & 7 days & lactose & yeast extract & {$[47]$} \\
\hline $\begin{array}{l}\text { Saccharomyces } \\
\text { cerevisiae }\end{array}$ & Invertase & 7 & 30 & $\mathrm{~ns}$ & $\mathrm{~ns}$ & 2 days & starch & urea & {$[42]$} \\
\hline $\begin{array}{l}\text { Scopulariopsis sp. } \\
\text { Protease }\end{array}$ & 9 & 37 & $\mathrm{n} \mathrm{s}$ & 3 & 5 days & casein & tryptone & {$[33]$} \\
\hline $\begin{array}{l}\text { Scytalidium } \\
\text { lignicola }\end{array}$ & Laccase & 6 & 30 & $\mathrm{~ns}$ & $\mathrm{~ns}$ & 7 days & sucrose & sodium nitrate & {$[43]$} \\
\hline Stereum ostrea & Laccase & 5.5 & 30 & 180 & $\mathrm{~ns}$ & 12 days & glucose & peptone & [65] \\
\hline $\begin{array}{l}\text { Trichoderma viride } \\
\text { Pers: SF Grey }\end{array}$ & $\begin{array}{c}\text { L-asparagi- } \\
\text { nase }\end{array}$ & 6.5 & 37 & $\mathrm{~ns}$ & $\mathrm{~ns}$ & 3 days & $\begin{array}{l}\text { L-asparagine } \\
\text { and peptone }\end{array}$ & {$[57]$} \\
\hline
\end{tabular}

Table 3: Optimum conditions for industrial enzymes produced by bacteria and fungi ns: not specified / not determined.

In addition, the higher industrial enzyme yields is obtained in a brief period of time. However, the physicochemical parameters are not easily monitored and regulated [32]. Some industrial enzymes were reported to be produced by both solid and submerged fermentation. For instance, the invertase ( $\beta$ D fructofuranosidase) was produced by Aspergillus sojae JU12 using SSF and the fermentation was cost effective as orange peels moistened with molasses were used. The enzyme is very important in the production of alcoholic beverages [26]. Similarly, the abundant agricultural residue known as lignocellulosic biomass was used to produce cellulase in significant amount with Aspergillus awamori [27].

Batch and fed batch fermentation, with constant and/or linear feeding, are also used for industrial enzyme production by microorganisms. Aishwarya., et al. [69] reported the production of a detergent protease by the bacterium Alcaligenes sp. (MTCC 9730) using fed batch fermentation. Different statistical experimental designs are used to produce industrial enzymes by microorganisms in higher amount. For instance, a sequential statistical strategy, by Plackett-Burman design followed by steepest ascent method and response surface methodology, was used to maximally produce tannase from Aspergillus [24]. Plackett-Burman design was used in SSF to produce a tannase by Aspergillus sp. GM4 [23].

The production of some industrial enzymes is stimulated by various substances in the production medium. For instance, the production of the detergent lipase by Bacillus flexus XJU-1 was activated by Tween-80 and Triton X-100. Indeed, the present surfactants act by modifying plasma membrane thereby activating the medium compounds uptake, leading to the lipase release in a significant amount [6,54]. Prasanna., et al. [47] reported the increase in extracellular cellulase secretion by Penicillium sp. when the surfactant Triton-X100 was supplemented to the fermentation medium. The production of laccase by a mushroom Stereum ostrea was stimulated by various inducers such as aromatic or phenolic compounds, copper and surfactants. Indeed, the micronutrient copper activates laccase transcription and production, whereas surfactants favor enzyme production by stimulating spores growth and enhancing the availability of less soluble substrates for the microorganism [65].

The use of the inexpensive by-products or agricultural residues does not make only the fermentation and production cost effective, but also reduces the environmental pollution that may be caused by by-products or agricultural residues disposition. Indeed, if a cheap substrate is chosen carefully to grow the microorganism, one third of process cost can be reduced [70]. For instance, keratinase was produced in a significant amount by Bacillus megaterium when chicken feathers were used as both carbon and nitrogen sources [59]. Similarly, Lincoln and More [71] optimally produce invertase from Aspergillus sojae JU12 when orange peel moistened with molasses were used as substrates. Likewise, wheat bran, a cheap agricultural substrate, was used by different Aspergillus species to produce phytase [22], keratinase [18], and laccase [65]. The coconut cake was also reported to be the best substrate for cellulase secretion by Pseudomonas fluorescens [46]. The table 2 shows some by-products or agricultural residues which are used as substrates during industrial enzymes production by microorganisms.

To meet the present increased industrial enzymes demand, the concomitant production of some enzymes by microorganisms in a single cultivation medium with cheap substrates becomes necessary. Industrial enzymes have been concomitantly produced from microorganisms and used in industries. Indeed, if two, three, or 
more industrial enzymes are coproduced by bacteria or fungi under similar conditions, the whole process is not expensive. In addtion, the stability among the simultanesously produced enzymes is assured. For example, protease, lipase, amylase, and cellulase are used in detergent industries to remove variious stains. If they are produced by the same cultivation medium, the proteolysis of lipase, amylase, and cellulase by the protease is prevented. No amylase or lipase proteolysis observed when the protease, lipase and amylase were coproduced together by Bacillus flexus XJU-1 in the same fermentation [54]. The amylases, cellulases, and lipases resistant to protease hydrolysis have an excellent applicability to the detergent formulation. The alkaline amylase of Bacillus megaterium B69 was also not hydrolyzed by the alkaline protease when concomittently produced together [72].

The agro-industrial byproducts were also used as inexpensive substrates for the simultaneous production of industrial enzymes in higher amounts. Shivakumar [73] coproduced an important amounts of amylase and protease by Bacillus sp. Y using cheap substrates under solid state fermentation. Similarly, the agro-industrial waste mustard oilseed cake was the substrate of choice for amylase and protease coproduction by Bacillus megaterium B69 [72]. Likewise, the inexpensive substrate was employed for the concomitant production of lipase and amylase by Bacillus subtilis JPBW-9 [74]. The use of the agricultural residue or byproducts as production substrates to produce industrial enzymes by microorganisms makes the fermentation process cost effective, and also avoid environmental pollution by using these wastes.

Optimization of process parameters for maximum industrial enzymes production by microorganisms

The industrial enzymes production by microorganisms is principally influenced by various factors such as incubation time, agitation/shaking, initial pH, inoculum concentration, incubation temperature, carbon source, metal ions, and nitrogen source (Table 3). The optimization of these process factors has a significant role in enhancing the industrial enzyme yield. The optimization of media components, cultural parameters and fermentation conditions is therefore necessary to maximally produce the industrial enzymes in adequate amounts. The process factors are generally optimized one factor each time, holding all other factors unchanged and the optimized condition/factor is taken into account in the subsequent experiments in sequential order. The advantage of the optimization of various nutritional parameters, physico-chemical aspects, and fermentation factors is that it helps in designing a cost effective fermentation process $[21,33,34,36,75]$.
The optimization of the process parameters by statistical methods are also used to increase the production of industrial enzymes in a shorter time. For instance, nutritional factors (C, N, and P sources) and physico-chemical parameters (inoculum age, incubation time and temperature) were optimized by applying Plackett-Burman design and the Box-Behken design and the enhancement in tannase production by Mucor circinelloides F6-3-12 was observed [63]. An adequate amount of lipase by was produced by Staphylococcus arlettae JPBW-1 using response surface methodology (RSM) [76]. Roy and Mukherjee [34] use Bacillus subtilis DM-03 and Bacillus licheniformis AS08E to maximally produce the amylases with statistical methods [34]. The culture conditions for the production of protease by Trichoderma estonicum was optimized by a 2-level factorial Plackett-Burman design followed by central composite design [39]. A list of various microorganisms producing industrial enzymes and the optimum conditions for the industrial enzymes production are shown in the table 3 .

Time course study for the industrial enzymes production by microorganisms

The incubation time plays an important role in the production of industrial enzymes by bacteria and fungi. The optimal time recorded for industrial enzymes production mainly ranged from 24 to $48 \mathrm{~h}$ for bacterial species [6,9-14,16,31,35,36,37,40,41,44,46,61,68,76]. The shorter incubation time reported for most of industrial enzymes production makes the fermentation process inexpensive. The incubation period of 60-96 $\mathrm{h}$ range was also reported for the production of industrial enzymes such as keratinase, protease, pullulanase, amylase and lipase by bacteria [5,7,14,34,59]. A higher incubation period of 120 and $168 \mathrm{~h}$ were observed for cyclodextrin glycosyltransferase (or CGTase) production by Bacillus flexus MSBC 2 [15] and amylase secretion by Streptomyces strain A3 [38], respectively (Table 3). Therefore, the time period of industrial enzymes secretion by bacteria varies from one species to another. This may be ascribed to the genomes difference.

The fungal industrial enzymes are secreted at optimal level at 4 or $5^{\text {th }}$ day $[17,18,21-23,25,26,33,56,64]$ (Table 3). A low fermentation time of 2 and 3 days was observed for the production of the invertases from the Saccharomyces cerevisiae [42] and L-asparaginase by Trichoderma viride Pers: SF Grey [57], respectively. The higher incubation time of 7 days was also noted for the production of pectinases by Aspergillus niger [20], cellulases by Penicillium sp. and Aspergillus awamori [27,47], tannase by Mucor circinelloides isolate F6-3-12 [63], and laccases by Scytalidium lignicola [43]. Likewise, Usha., et al. [65] reported a higher incubation time of 12 days when laccase was secreted in an adequate amounts by Stereum ostrea. 
In general, as the incubation time increases, the industrial enzymes secretion by microorganisms also increases. However, after optimum incubation period, a decline in industrial enzyme production is observed. This decrease in industrial enzymes production was attributed to the reduced availability of nutrients and the toxic metabolites secretion [77] or decomposition of industrial enzyme by the protease [78]. For industrial lipase, the decrease was ascribed to the accumulation of fatty acids and glycerol resulted from lipolysis [79]. For most industrial enzymes like amylases, the decrease in amylase production was due to the enzyme denaturation resulted from the enzyme produced and the medium components interaction $[52,53]$. The variation in industrial enzyme production by bacteria and fungi can be attributed to growth and metabolic activities variation $[53,80]$.

Influence of initial $\mathrm{pH}$ of the medium on industrial enzymes production by microorganisms

The initial $\mathrm{pH}$ of the culture and fermentation medium is a major factor regulating industrial microbial enzymes secretion. It may influence the availability of nutrient substrates or the transport of various nutrient components across the bacterial or fungal membranes, which in turn stimulates the microbial growth and thus industrial enzymes production $[53,75,80]$. The optimum initial $\mathrm{pH}$ range recorded for most of the industrial bacterial enzymes is the 6 to 10 range [5-7,9,11-13,15,16,34,35-38,40,41,44,46,59,61,68,76]. A low pH of 5.0 and 5.5 was seen for amylase production by Chryseobacterium sp. [14] and phytase by Bacillus lehensis MLB2 [10], respectively. 10.5 was higher $\mathrm{pH}$ recorded for industrial CG Tase production by Bacillus halodurans [31] (Table 3). The difference in genomes may also be the reason why the bacteria producing industrial enzymes have different initial $\mathrm{pH}$ requirements.

The optimum pH observed for fungal industrial enzymes production ranges from acidic to basic pH range, viz. $\mathrm{pH} 5$ to 9 [17,18,25-27,33,42,43,47,56,57,63-65]. Niyonzima and More [21] produced an alkaline protease active at $\mathrm{pH}$ of 10.0 using Aspergillus terreus gr. Similary, lower $\mathrm{pH}$ values of 4 and 4.5 were observed as optimum initial $\mathrm{pH}$ in the production of tannase, phytase, and pectinases by Aspergillus species [20,22,23] (Table 3). The variation in industrial enzyme yields at different initial pH requirement may be due to the bacterial or fungal strain specificity. Any deviation from optimum initial $\mathrm{pH}$ resulted in low industrial enzyme secretion. This was attributed to the disruption of transport mechanisms through the bacterial or fungal membrane that prevents the industrial enzyme release [81].
Effect of incubation temperature on the industrial enzymes production by microorganisms

The incubation temperature is a vital environmental parameter for industrial enzymes secretion by microorganisms. Like initial $\mathrm{pH}$, it may influence the growth of bacteria and fungi, and thus industrial bacterial or fungal enzymes production. The optimum incubation temperature seen for bacterial industrial enzymes production is in the 30 to $50^{\circ} \mathrm{C}$ range. $37^{\circ} \mathrm{C}$ was noted as optimum production temperature in most cases [3,5,6,9-12,31,32,35,36,59,61] (Table 3). A low optimum incubation temperature of 20 and $28{ }^{\circ} \mathrm{C}$ were also observed for industrial amylase and lipase production, respectively by Bacillus species [7,40]. For fungal species, the optimum incubation temperature is ranged from 25 to $47^{\circ} \mathrm{C}[17,18,20$ 23,25-27,33,42,43,47,56,57,63-65]. However, $60^{\circ} \mathrm{C}$ was optimum fermentation temperature for $\beta$-amaylase production by Penicillium nigricans [45]. At elevated incubation temperature, the yield in industrial enzymes production is low due to the thermoliability of the industrial enzymes or the denaturing of industrial enzyme structure in the active site.

Effect of inoculum level on the industrial enzymes production by microorganisms

The concentration of inoculum is one of the key culture parameters for microbial growth and thus industrial enzymes production. Various inoculum concentrations ranging from 0.6 to $4 \%$ were optimum for bacterial industrial enzymes production by microorganisms [3,6,10,14,32,36-38,40,41] (Table 3). However, Chauhan., et al. [76] reported a detergent lipase production by Staphylococcus arlettae JPBW-1 when a higher inoculum size of $10 \%$ was used. Different inoculum levels were found to maximally produce the industrial enzymes by different fungi. For instance, the inoculum level of $2 \%$ was optimum for the tannase production by Mucor circinelloides isolate F6-3-12 [63] and protease production by Aspergillus terreus gr. [21]. 3\% was inoculum size optimum for the secretion of a protease by Scopulariopsis sp. [33]. Lincoln and More [71] obtained an industrial invertase from Aspergillus sojae JU12 using a higher inoculum level of $9 \%$. The effect of inoculum on industrial enzymes secretion may thus depend on the type of microorganism, inoculum load, and the bacterial or fungal size, and type.

Generally, an important increase in industrial enzymes production by microorganisms correlated with an enhancement in inoculum concentration till optimum inoculum size reached [21,33] owing to rapid substrate degradation [82]. Indeed, the industrial enzyme production by microorganisms is often high at lower inoculum levels; however, a low industrial enzyme yield is observed 
after optimum inoculum size [83]. Hesseltine., et al. [84] proposed that the decrease observed when an important inoculum level is used can be attributed to the faster bacterial or fungal growth and thus shortage of the nutrients. Likewise, Hasan., et al. [14] observed a low yield at higher inoculum level owing to the lack of total dissolved oxygen and nutrient supply to the microorganisms.

Effect of carbon source on industrial enzymes production by microorganisms

The carbon sources serve as a primary energy source for bacterial and fungal growth and therefore industrial enzymes production. The carbon sources such as starch $[4,14,15,32,68]$ glucose $[9,14,46]$, soluble pullulan $[5,11]$, malt extract [12], maltose [16,38], pullulan [5], sucrose [35], and carboxymethylcellulose [13] are used for the production of the bacterial industrial enzymes. Soybean oil [76], olive oil [41] and cotton seed oil [6] were also used as carbon sources. In some cases, a mixture of carbon sources like corn flour and bean flour [32], glucose and skim milk [3], and glucose and sesame oil [40] are used in the secretion of bacterial enzymes (Table 3 ).

For the production of industrial fungal enzymes, starch [42,45], glucose [22,56,65], maltose [57], sucrose [43], lactose [47], carboxymethylcellulose [27], pectin [20], and tannate [25] are employed as carbon sources. Various inexpensive substances such wheat bran [17], jamun leaves [23], green tea leaves [63], and orange peel moistened with molasses [26] were preferred as carbon sources for industrial enzymes production by fungi. The industrial enzymes are generally produced by microorganisms with low carbon source concentration. This make the production cost effective used. In some cases, a carbon source repression is obsrved when a carbon source is used in a significant amout. When an important amount of carbon source is utilized, industrial enzymes secretion decreased owing to limitation of oxygen transfer resulting in poor bacterial or fungal growth [6].

Effect of nitrogen sources on industrial enzymes production by microorganisms

The nitrogen sources served as a secondary energy source for the microbial growth and thus for industrial enzymes production. They play an important role in most of the microorganisms to synthetize the cell wall components, amino acids, peptides, proteins (including industrial enzymes), and nucleotides / nucleic acids [85]. For the production of bacterial industrial enzymes, tryptone [11], peptone $[5,12,14,38]$, yeast extract $[6,9,36,44]$, and beef extract [4] are employed (Table 3). Sometimes, the optimum industrial enzymes production is observed when there is combination of nitrogen sources, like peptone and yeast extract $[15,31,41,68]$. The cheap organic nitrogen sources like corn flour and bean flour [32] and soybean meal [40] are also utilized to produce industrial enzymes by bacteria.

Like for bacteria, organic nitrogen sources such as peptone $[18,20,27,65]$, tryptone [33], urea [42], yeast extract [25,47], beef extract [26], and L-asparagine [56] are used in industrial fungal enzymes production. In general, the industrial enzymes are generally produced at their optimum levels when organic nitrogen sources are incorporated in the production medium. The preference of organic nitrogen sources by industrial enzymes producing microorganisms can be ascribed to the presence of some micro-and micronutrients, vitamins, amino acids and/or peptides, and growth factors present in them $[33,36,37]$ (Table 3).

The feather meal served as both carbon and nitrogen carbon source for industrial keratinase production by Bacillus megaterium [59]. The nitrogen sources stimulate the industrial enzymes production up to certain level beyond which a nitrogen metabolite repression is seen. Indeed, the complex organic nitrogen sources may show industrial enzymes repression when employed in high amounts because they are rich in amino acids (such as glycine and valine) and short peptides. A higher nitrogen source concentration is therefore inhibitory to the industrial enzyme secretion by bacteria or fungi.

Although the inorganic nitrogen sources are not generally often found to increase the production of the industrial enzymes, an important industrial enzymes production was observed in some cases with them. For instance, a significant industrial enzyme production was seen when ammonium acetate [7], potassium nitrate [10], and ammonium sulfate $[46,61]$ were used from industrial production by bacteria. Similarly, ammonium nitrate [22], potassium nitrate [23], sodium nitrate $[17,43,63]$ and sodium nitrite [45] were inorganic nitrogen sources used to produce industrial enzymes by fungi.

\section{Effect of agitation on the industrial enzymes production}

The industrial enzymes-producing microorganisms are usually grown under shaking conditions. The production of bacterial industrial enzymes is often done with shaking in the range of 100 to $200 \mathrm{rev} / \mathrm{min}$ (Table 3). For instance, $100 \mathrm{rpm}$ was the optimum for the production of industrial enzymes by Bacillus species $[6,10,16]$, while $200 \mathrm{rpm}$ was also best for some bacterial species $[11,34,36,38,44]$. Similarly, the production of industrial enzymes by fungi was agitated in the 120 to $200 \mathrm{rev} / \mathrm{min}$ range. For examples, $120 \mathrm{rpm}$ [18,25], 150 [17,20], 160 [64], 180 [65], and 200 
rpm $[22,63]$ were found as optimal shaking conditions for fungal species. The agitation of the culture flasks at a moderate rate allows a good availability of the nutrients to the microorganisms and a proper aeration, favoring thus the production of industrial enzymes in important amounts.

\section{Conclusion}

In the present review, an overview was given for the production and optimization of nutritional and physical parameters of industrial enzymes. Since there is a nonstop demand of industrial enzymes, the present information can help the other researchers to optimize industrial enzymes production cost effectively. Although various industrial enzymes have been produced under optimized conditions in the last decade, most of them are not marketed. This was mainly attributed to the non-cost-effective production and lack of enzymes with desired properties. The intensive studies are still needed to get bacterial or fungal industrial enzymes with better properties. The various companies must thus work together with academic institutions to strength this linkage.

\section{Acknowledgments}

Author is thankful to INES Ruhengeri management for support.

\section{Conflict of Interest}

Author has no conflict of interests.

\section{Bibliography}

1. Nelson DL and Cox MM. "Lehninger principles of biochemistry". 5th ed, W.H. Freeman and Company (2008).

2. Willey JM., et al. "Prescott Harley Klein's microbiology". 7th ed, Mc Graw Hill, (2008).

3. Beena AK., et al. "Detergent potential of a spoilage protease enzyme liberated by a psychrotrophic spore former isolated from sterilized skim milk". American Journal of Food Technology 7 (2012): 89-95.

4. Roy JK., et al. "Characterization and application of a detergent-stable alkaline $\alpha$-amylase from Bacillus subtilis strain AS-S01a". International Journal of Biological Macromolecules 50 (2012): 219-229.

5. Asha R., et al. "Purification and properties of pullulanase from Bacillus halodurans". International Research Journal of Biological Sciences 2 (2013): 35-43.

6. Niyonzima FN., et al. "Optimization of fermentation culture conditions for alkaline lipase production by Bacillus flexus XJU-1". Current Trends in Biotechnology and Pharmacy 7 (2013): 793-803.
7. Roohi R., et al. "Cold-active detergent-stable extracellular $\alpha$-amylase from Bacillus cereus GA6: Biochemical characteristics and its perspectives in laundry detergent formulation". Journal of Biochemical Technology 4 (2013): 636-644.

8. Saracoglu ZN., et al. "Characterization of an oxidant and detergent stable alkaline protease produced from a novel isolate Bacillus sp. strain". Journal of Applied Biological Sciences 7 (2013): 4-9.

9. Mathur A., et al. "Isolation, purification and characterization of alkaline pectinase from Bacillus subtilis isolated from soil". Journal of Pharmaceutical Sciences 5 (2014): 1-6.

10. More SS., et al. "Purification and characterization of phytase from Bacillus lehensis MLB2". Biologia 70 (2015): 294-304.

11. Waleed M., et al. "Production optimization of pullulanase enzyme produced by Bacillus cereus isolated from Syrian sources". International Food Research Journal 22 (2015): 18241830.

12. Sinha S and Nigam VK. "Production and characterization of L-glutaminase by Bacillus sp". International Journal of Pharmaceutical Sciences and Research 7 (2016): 1620-1626.

13. Sriariyanun M., et al. "Production, purification and characterization of an ionic liquid tolerant cellulase from Bacillus sp. isolated from rice paddy field soil". Electronic Journal of Biotechnology 19 (2016): 23-28.

14. Hasan MM., et al. "Optimization of some fermentation conditions for the production of extracellular amylases by using Chryseobacterium and Bacillus isolates from organic kitchen wastes". Journal of Genetic Engineering and Biotechnology 15 (2017): 59-68.

15. Shwetha V., et al. "Screening, optimization and production of a novel $\beta$-cyclodextrinase by Bacillus flexus MSBC 2 ". Current Trends in Biotechnology and Pharmacy 11 (2017): 136-143.

16. More SS., et al. "Purification and characterization of anti-cancer L-glutaminase of Bacillus cereus strain LC13". Proceedings of the National Academy Sciences 88 (2018): 695-705.

17. Choudhary V. "Production, isolation and characterization of alkaline protease from Aspergillus versicolor PF/F/107". Journal of Academia and Industrial Research 1 (2012): 272277.

18. Mini KD., et al. "Screening of fungi isolated from poultry farm soil for keratinolytic activity". Advances in Applied Science Research 3 (2012): 2073-2077.

19. Pundir RK., et al. "Studies on compatibility of fungal alkaline protease with commercially available detergents". International Journal of Modern Biochemistry 1 (2012): 41-56. 
20. Dhital R., et al. "Optimization of cultural conditions for the production of pectinase from selected fungal strain". Journal of Food Science and Technology 8 (2013): 65-70.

21. Niyonzima FN and More SS. "Screening and optimization of cultural parameters for an alkaline protease production by Aspergillus terreus gr. under submerged fermentation". International Journal of Pharma and Bio Sciences 4 (2013): 1016-1028.

22. Sandhya A., et al. "Production and optimization of phytase by Aspergillus niger”. Der Pharmacia Lettre 7 (2015): 148-153.

23. Souza PNC., et al. "Optimization of culture conditions for tannase production by Aspergillus sp. gm4 in solid state fermentation". Acta Science 37 (2015): 23-30.

24. Xiao A., et al. "Statistical optimization for tannase production by Aspergillus tubingensis in solid-state fermentation using tea stalks". Electronic Journal of Biotechnology 18 (2015): 143-147.

25. Cavalcanti RMF., et al. "Screening, selection and optimization of the culture conditions for tannase production by endophytic fungi isolated from Caatinga". Journal of Applied Biology and Biotechnology 5 (2017): 1-9.

26. Lincoln L and More SS. "Screening and enhanced production of neutral invertase from Aspergillus sp. by utilization of molasses - A by-product of sugarcane industry". Advances in Bioresearch 8 (2017): 103-110.

27. Pachauri P., et al. "Kinetic study and characterization of cellulase enzyme from isolated Aspergillus niger subsp. awamori for cellulosic biofuels". Journal of Science and Industrial Research 77 (2018): 55-60.

28. Ire FS., et al. "Influence of cultivation conditions on the production of a protease from Aspergillus carbonarius using submerged fermentation". African Journal of Food Sciences 5 (2011): 353-365.

29. Kumar CG and Takagi H. "Microbial alkaline protease: from bioindustrial viewpoint". Biotechnology Advances 17 (1999): 561-594

30. Hajji M., et al. "Optimization of alkaline protease production by Aspergillus clavatus ES1 in Mirabilis jalapa tuber powder using statistical experimental design". Applied Microbiology and Biotechnology 79 (2008): 915-923.

31. More SS., et al. "Isolation, purification and biochemical characterization of CGTase from Bacillus halodurans". Croatian Journal of Food Technology, Biotechnology and Nutrition 7 (2012): 26-33.
32. Wang H., et al. "Screening and characterization of a novel alkaline lipase from Acinetobacter calcoaceticus 1-7 isolated from Bohai bay in China for detergent formulation". Brazilian Journal of Microbiology 43 (2012): 148-156.

33. Niyonzima FN and More SS. "Optimization of fermentation culture conditions for alkaline protease production by Scopulariopsis sp". Applied Biological Reserach 15 (2013): 66-69.

34. Roy JK and Mukherjee AK. "Applications of a high maltose forming, thermo-stable $\alpha$-amylase from an extremely alkalophilic Bacillus licheniformis strain AS08E in food and laundry detergent industries". Biochemical Engineering Journal 77 (2013): 220-230.

35. Hussain AA., et al. "Optimization and molecular identification of novel cellulose degrading bacteria isolated from Egyptian environment". Journal of Genetic Engineering and Biotechnology 15 (2017): 77-85.

36. Pathak AP and Deshmukh KB. "Alkaline protease production, extraction and characterization from alkaliphilic Bacillus licheniformis KBDL4: A lonar soda lake isolate". Indian Journal of Experimental Biology 50 (2012): 569-576.

37. Sinha R and Khare SK. "Isolation and characterization of halophilic Virgibacillus sp. EMB13: Purification and characterization of its protease for detergent application". Indian Journal of Biotechnology 11 (2012): 416-426.

38. Chakraborty S., et al. "Study on calcium ion independent $\alpha$-amylase from haloalkaliphilic marine Streptomyces strain A3". Indian Journal of Biotechnology 11 (2012): 427-437.

39. Saravanakumar K and Kathiresan K. "Statistical optimization of protease production by mangrove-derived Trichoderma estonicum and its potential on blood stain removal". International Journal of Biotechnology and Molecular Biology Research 3 (2012): 15-21.

40. Lailaja VP and Chandrasekaran M. "Detergent compatible alkaline lipase produced by marine Bacillus smithii BTMS 11". World Journal of Microbiology and Biotechnology 29 (2013): 1349-1360.

41. Nerurkar M., et al. "Application of lipase from marine bacteria Bacillus sonorensis as an additive in detergent formulation". Journal of Surfactants and Detergents 16 (2013): 435-443.

42. Sivakumar T., et al. "Production of extracellular invertase from Saccharomyces cerevisiae strain isolated from grapes". International Journal of Current Research and Academic Review 1 (2013): 72-83.

43. Sidhu AK., et al. "Isolation, screening and optimization for laccase production by Scytalidium lignicola pesante under submerged fermentation". International Journal of Current Microbiology amd Applied Sciences 6 (2017): 2477-2491. 
44. Maalej H., et al. "Purification and biochemical characterization of a detergent stable $\alpha$-amylase from Pseudomonas stutzeri AS22". Biotechnology and Bioprocess Engineering 18 (2013): 878-887.

45. Uday MM., et al. "Isolation and characterization of $\beta$-amylase from Penicillium nigricans". BioTechnology an Indian Journal 7 (2013): 85-88.

46. Sethi S., et al. Optimization of cellulase production from bacteria isolated from soil (2013).

47. Prasanna HN., et al. "Optimization of cellulase production by Penicillium sp.”. 3 Biotech 6 (2016): 162-172.

48. Niyonzima FN and More SS. "Biochemical properties of the alkaline lipase of Bacillus flexus XJU-1 and its detergent compatibility". Biologia 69 (2014): 1108-1117.

49. Amara AA., et al. "The possibility to use bacterial protease and lipase as a detergent". Global Journal of Biotechnology and Biochemistry 4 (2009): 104-114.

50. Hou CT and Johnston TM. "Screening of lipase activities with cultures from the agricultural research services culture collection". Journal of the American Oil Chemists' Society 69 (1992): 1088-1097.

51. Niyonzima FN and More SS. "Purification and properties of detergent compatible extracellular alkaline protease from Scopulariopsis sp". Preparative Biochemistry and Biotechnology 44 (2014): 738-759.

52. Niyonzima FN and More SS. "Purification and characterization of detergent compatible alkaline protease from Aspergillus terreus gr". 3 Biotech 5 (2015): 61-70.

53. Niyonzima FN and More SS. "Detergent compatible proteases: Microbial production, properties and stain removal analysis". Preparative Biochemistry and Biotechnology 45 (2015): 233-258.

54. Niyonzima FN and More SS. "Concomitant production of detergent compatible enzymes by Bacillus flexus XJU-1". Brazilian Journal of Microbiology 45 (2014): 903-910.

55. Niyonzima FN and More SS. "Detergent compatible bacterial amylases". Applied Biochemistry and Biotechnology 174 (2014): 1215-1232.

56. Thakur M., et al. "Isolation, purification and characterization of fungal extracellular L-asparaginase". Journal of Biocatalysis and Biotransformation 2 (2014).

57. Lincoln L., et al. "Purification and properties of a fungal Lasparaginase from Trichoderma viride Pers: SF Grey". Journal of Microbiology, Biotechnology and Food Sciences 4 (2015): 310-316.
58. Grant WD., et al. "An alkalophilic species of Ectothiorhodospira from a Kenyan soda lake". Journal of Genetic Microbiology 110 (1979): 137-142.

59. Saibabu V., et al. "Isolation, partial purification and characterization of keratinase from Bacillus megaterium". International Research Journal of Biological Sciences 2 (2013): 13-20.

60. Khoramnia A., et al. "Production of a solvent, detergent, and thermotolerant lipase by a newly isolated Acinetobacter sp. in submerged and solid-state fermentations". Journal of Biomedicine and Biotechnology (2011).

61. Ghasemi Y., et al. "Isolation and identification of highly xylanase producing bacterium Sphingobacterium sp. SaH-05 from soil". International Journal of Scientific and Engineering Research 5 (2014): 205-209.

62. Koneman W., et al. "Colour atlas and textbook of diagnostic microbiology". J.B Lippincott Company, (1997).

63. El-Refai HA., et al. "Statistical optimization for tannase production by Mucor circinelloides isolate F6-3-12 under submerged and solid state fermentation". Current Trends of Biotechnology and Pharmacy 11 (2017): 167-180.

64. Sharma P., et al. "Isolation, screening, characterization and optimization of xylanase production from thermostable alkalophillic Fusarium sp. XPF5". Journal of Biochemical Technology 7 (2016): 1089-1092.

65. Usha KY., et al. "Enhanced production of ligninolytic enzymes by a mushroom Stereum ostrea". Biotechnology Reserach International (2014).

66. Sarrouh B., et al. "Up-to-date insight on industrial enzymes applications and global market". Journal of Bioprocessing and Biotechniques (2012): S4:002.

67. Rao MB., et al. "Molecular and biotechnological aspects of microbial protease". Microbiology and Molecular Biology Review 62 (1998): 597-635.

68. Rodrigues PM., et al. "Stability and activity of the partially purified spray-dried protease from Bacillus sp SMIA-2 and its characterization as a laundry detergent additive". International Journal of Bioassays 2 (2013): 562-567.

69. Aishwarya M., et al. "Production, characterization and purification of alkaline protease from Alcaligenes sp. and its application in detergent industry". Asian Journal of Pharmaceutical and Clinical Research 6 (2013): 151-155.

70. Niyonzima FN and More SS. "Coproduction of detergent compatible bacterial enzymes and stain removal evaluation". Journal of Basic Microbiology 55 (2015): 1-10. 
71. Lincoln L and More SS. "Purification and biochemical characterization of an extracellular $\beta d$ fructofuranosidase from Aspergillus sp". 3 Biotech 8.2 (2018): 86.

72. Saxena R and Singh R. "Contemporaneous production of amylase and protease through CCD response surface methodology by newly isolated Bacillus megaterium strain B 69". Enzyme Research (2014).

73. Shivakumar S. "Co-production of alkaline protease and amylase of Bacillus sp. Y in solid state cultivations". Research Journal of Biotechnology 7 (2012): 32-38.

74. Anwar T., et al. "Statistical optimization for coproduction and partial characterization of thermohalotolerant lipase and amylase from halotolerant Bacillus subtilis JPBW-9". World Journal of Science and Technology 1 (2011): 54-63.

75. Bora L and Bora M. "Optimization of extracellular thermophilic highly alkaline lipase from thermophilic Bacillus sp. isolated from hot spring of Arunachal Pradesh, India". Brazilian Journal of Microbiology 43 (2012): 30-42.

76. Chauhan M., et al. "Evaluation of a new lipase from Staphylococcus sp. for detergent additive capability". BioMed Research International (2013): 374967.

77. Romero F., et al. "Protease production from whey at high concentration by Serratia marcescens". Resource and Environemetal Biotechnology 2 (1998): 93-115.

78. Anandan D., et al. "Isolation, characterization and optimization of culture parameters for production of an alkaline protease isolated from Aspergillus tamarii". Journal of Industrial Microbiology and Biotechnology 34 (2007): 339-347.

79. Smith JL and Alford JA. "Inhibition of microbial lipases by fatty acids". Applied Microbiology 14 (1996): 699-705.

80. Bhavani M., et al. "Screening, isolation and biochemical characterization of novel lipase producing bacteria from soil samples". International of Journal and Biological Engineering 2 (2012): 18-22.

81. Padhiar J., et al. "Optimization of process parameters influencing the submerged fermentation of extracellular lipases from Pseudomonas aeruginosa, Candida albicans and Aspergillus flavus". Pakistan Journal of Biological Sciences 14 (2011): 1011-1018.

82. Sarao LK., et al. "Production of protease by submerged fermentation using Rhizopus microsporus Var Oligospous". Internet Journal of Microbiology 9.1 (2010).

83. De Souza DF, et al. "Effect of easily metabolizable sugars in the production of xylanase by Aspergillus tamarii in solidstate fermentation". Process Biochemistry 36 (2001): 835838.
84. Hesseltine CW. "Biotechnology report: Solid-state fermentations". Biotechnology and Bioengineering 14 (1972): 517-532.

85. Gupta R., et al. "An overview on fermentation, downstream processing and properties of microbial alkaline proteases". Applied Microbiology and Biotechnology 60 (2002): 381-395.

\section{Volume 2 Issue 12 December 2019 (C) All rights are reserved by Francois Niyongabo Niyonzima.}

